\title{
The Decline Of Manufacturing In The United States And Its Impact On Income Inequality
}

John H. Dunn, Jr., MBA, Robert Morris University, USA

\begin{abstract}
The decline of manufacturing in the United States has been a perceptible trend, starting in the aftermath of World War II when manufacturing represented over one quarter of our Gross Domestic Product, to today, when it is less than 12\%. The unemployment of the Great Recession, and the most recent State of the Union Address by President Obama, have now made this front page news. The declining trend has been masked by the facts that the U.S. remains, in total, the world's largest manufacturer, and, along with China, the top value added producers. A second trend has been the decline of manufacturing employment as a percentage of the total labor force, running from just under one quarter post WWII, to less than 8\% today. And finally the third trend has been the premium of manufacturing compensation versus all industries, from $11 \%$ in 1950 to $23 \%$ in 2010. Together these three trends are the major components of the increasingly palpable trend of income inequality from 1950 to 2010. In 1950 the top $20 \%$ had $17.3 \%$ of family income, whereas in 2010 it was 20\%. The Gini coefficient, another measure of negative income distribution, moved from .379 to .440 over the same time frame.
\end{abstract}

Keywords: Manufacturing; United States Family Income; Industrial Policy

\section{THE DECLINE OF MANUFACTURING}

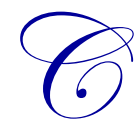

hart One, constructed from information obtained from both the Bureau of Labor Statistics and the Bureau of Economic Analysis, details the actual decline of manufacturing as a percent of the GDP and as a percent of the Labor Force since 1950. In 2010 there were actually fewer people employed in manufacturing than in 1950 .

There are several misconceptions and misperceptions of the manufacturing decline. The public seemed to believe that service jobs' replacing manufacturing jobs was progress. The vision of moving from manufacturing in dirty, environmentally unfriendly traditional industries versus employment in technology, intellectual property, or healthcare seemed compelling. But even those jobs have not remained in America. As the former head of Intel, Andy Grove, points out (1), "today manufacturing in the U.S. computer industry has about 166,000 employees, lower than... in 1975", whereas in Asia computer manufacturing employs "about 1.5 million workers, factory employees, engineers, and managers". For the most part, manufacturing jobs are solidly middle class, whereas service jobs cover an income spectrum from computer programmers to hamburger flippers. And yet, "you have a culture within the elites of both political parties that says manufacturing does not matter..." (2).

The fact that "output continues to rise, reaching $\$ 1.95$ trillion last year" (2), and that "the United States remains the world's largest manufacturer"(3), allows the public perception to be that we're simply making more with fewer people. But if manufacturing had remained in other than a declining mode, then the great strides in automation and productivity would have seen far greater increases in output. That "the United States remains home to an important fraction of the world's manufacturing value added... roughly $20 \%$ for 2009 " (4) seems to keep us comfortable. The fact is that Chinese manufacturers generated \$1.7 trillion of 'value added' versus America's \$1.6 trillion. (2) Lost in these numbers is the economic fact that "each new manufacturing job generates five others in the 
economy. Shrinking the relative size of manufacturing has undermined that multiplier effect." (2). Put another way, "For every $\$ 1.00$ spent in manufacturing, another $\$ 1.35$ is added to the economy" (9). This compares favorably to the impact of the Marcellus shale find on the Pennsylvanian economy: "For every $\$ 1$ that the Marcellus industry spends in the state, $\$ 1.94$ of total economic output is generated... and for every $\$ 1$ million of output created by natural gas production in the Pennsylvania Marcellus, 6.9 jobs are created." (10)

Chart One: The Statistical Decline of Manufacturing Manufacturing as a \% of U. S. Labor Force

\begin{tabular}{|c|c|c|c|c|}
\hline \multicolumn{3}{|c|}{ Manufacturing as a \% of U.S. Labor Force } & \multicolumn{2}{|c|}{ As a \% of GDP } \\
\hline & & 1 & & \\
\hline Year & $\begin{array}{l}\text { Manufacturing Jobs } \\
\text { in 000s }\end{array}$ & $\begin{array}{l}\text { Total Labor Force } \\
\text { in 000s }\end{array}$ & $\%$ & $\%$ \\
\hline 1950 & 14,782 & 62,068 & $23.8 \%$ & $27.0 \%$ \\
\hline 1960 & 14,947 & 70395 & $21.2 \%$ & $25.3 \%$ \\
\hline 1970 & 17,309 & 83,670 & $20.7 \%$ & $22.7 \%$ \\
\hline 1980 & 18,640 & 107,352 & $17.4 \%$ & $20.0 \%$ \\
\hline 1990 & 17,394 & 126,142 & $13.8 \%$ & $16.7 \%$ \\
\hline 2000 & 17,178 & 143,248 & $12.0 \%$ & $14.2 \%$ \\
\hline 2010 & 11,565 & 153,690 & $7.5 \%$ & $11.7 \%$ \\
\hline
\end{tabular}

1. Source: Bureau of Labor Statistics

2. Source: Bureau of Economic Analysis

What are the main causes of the decline in manufacturing? Surprisingly labor is far from the root cause. Using Detroit as a proxy for labor costs, where "wages make up about $10 \%$ of a car's cost..." that would hardly be a major factor. "If the U.S. lost manufacturing due to high wages ... how do you explain the manufacturing success of Germany and Japan? Germany, the world's pre-eminent high end manufacturing economy, has higher wages, stronger unions and stricter labor laws than the U.S." (5) In many cases shipping costs equal or exceed labor savings.

One cause of the problem is corporate taxes. Nominally the U.S. has the highest corporate tax rate in the world. In actuality, due to a tax code that is the product of lobbying and parochial legislation, the tax rate is very uneven, and there are winners and losers. Federal "subsidies" exist for the energy, natural resources, agribusiness, pharmaceutical, and intellectual property industries. Without passing judgment, all are familiar with the generous depletion allowances for the energy industry. But GAAP accounting rules contribute to the penalties faced by manufacturers. For example, if a steel manufacturer builds a new plant, lengthy depreciation schedules unfairly magnify taxable profits. Whereas those in the pharmaceutical industry essentially expense their R\&D, deferring future profits and taxes. You can make a case that manufacturing subsidizes other industries. [Certainly tax policy affects free cash flow, which Wall Street uses for valuation far more than profits/earnings. So why not tax cash flow instead of accounting profits? Matching revenues and expenses is more of an art than a science, despite obvious protest that would occur from the AICPA]. And the net result of these tax policies: manufactures move off shore, where tax repatriation never happens.

A second cause for the decline of manufacturing would be unfair trade policies. Through the Fourteenth Amendment, we insure that trade laws do not vary from state to state. We expect our government to enforce worker safety practices, an equitable wage, patents and trademarks, child labor restrictions, contracts, and regulations for product safety, as well as to protect the environment. But other countries vary considerably in all of the above laws either lacking or ignoring. Compare the reported worker deaths in 2009 in China, 83,196 to the U.S., 5,071. (6) An article in the New York Times detailed both working conditions and apparent suicides in Foxconn, the world's largest contract electronics supplier (7). Contrast the Economic Theory of Comparative Advantage, where product specialization theoretically allows countries to gain making certain products, to the present situation where countries gain by dismissing environmental, safety or intellectual property rights, or by central government subsidies.

Other causes would include healthcare and other legacy costs, and infrastructure. A client of mine visited a factory in China, comparable to one of his in America. He asked about their electricity costs (since his were 
relatively high). His response was a nearly a blank stare as his Chinese counterpart said that the state supplies power at no charge. Excessive litigation costs - both direct and indirect - are another cause. In 2003 legal costs in the U.S. were $2.2 \%$ of the GDP versus about $1 \%$ in Europe.(8) Finally, the issue most often raised by American manufacturers is that there are countless American duplicative laws, rules, regulations, and permits that raise expensive costs for those companies. Most CEOs polled during the Great Recession cited uncertainty in the economy, especially regarding tax and healthcare costs, as a significant restraint against new investment. Reducing these costs would allow for more investment in hiring and training. Traditionally business investment has been close to $17 \%$ of the GDP as opposed to the present $12.6 \%$.

Obviously the above causes of the decline in America's manufacturing are not the only reason that U.S. companies produce off shore. Meeting local purchasing/consumer demand is very significant, especially for multinationals. That said, there are countless reforms in addition to the President's new quasi industrial policy that can increase our manufacturing base. At the end of the day there must be "fair trade" policies that limit our imports, or a reduction of the companies' costs of capital.

\section{THE POLARIZATION OF INCOMES IN AMERICA}

Chart Two: The Polarization of Incomes Income Distribution

\begin{tabular}{|c|c|c|c|c|c|c|}
\hline \multicolumn{4}{|c|}{ Family Income } & \multicolumn{3}{|c|}{ Household Income } \\
\hline \multicolumn{4}{|c|}{ Share of Income } & \multicolumn{3}{|c|}{ Share of Income } \\
\hline Year & Bottom Fifth & Top Fifth & Gini Index & Bottom Fifth & Top Fifth & Gini Index \\
\hline 2010 & $3.8 \%$ & $20.0 \%$ & 0.440 & $3.3 \%$ & $21.3 \%$ & 0.469 \\
\hline 2000 & $4.3 \%$ & $21.1 \%$ & 0.433 & $3.6 \%$ & $22.1 \%$ & 0.462 \\
\hline 1990 & $4.6 \%$ & $17.4 \%$ & 0.396 & $3.8 \%$ & $18.5 \%$ & 0.428 \\
\hline 1980 & $5.3 \%$ & $14.6 \%$ & 0.365 & $4.2 \%$ & $16.5 \%$ & 0.403 \\
\hline 1970 & $5.4 \%$ & $15.6 \%$ & 0.353 & $4.1 \%$ & $16.6 \%$ & 0.394 \\
\hline 1960 & $4.8 \%$ & $15.9 \%$ & 0.364 & NA & NA & NA \\
\hline 1950 & $4.5 \%$ & $17.3 \%$ & 0.379 & NA & NA & NA \\
\hline
\end{tabular}

Source: U.S. Census Bureau

Incomes of Families began being charted in 1947. In 1967 the Census Bureau added a second measure of incomes in America: Incomes from Households, where non-family members live together and contribute income. Finally, use in both Incomes is made of the Gini coefficient or index, developed in 1912 by Corrado Gini.(11) It is a measure of the inequality of income, with 0 being total equality and 1 being total inequality, i.e. the higher the Gini index, the greater the inequality.

Chart Two shows both measures of income, with the respective Gini indices for both. For illustrative purposes, the top and bottom $20^{\text {th }}$ percentiles are included. (12)The results are dramatic: In family income, since 1950 the bottom fifth have lost $15.5 \%$ share of income while the top fifth has gained 15.6\%. Statistically, the Gini index shows a similar increase in inequality of $16.1 \%$. Household incomes tell a similar story, but more magnified: the bottom fifth lost 19.5\% (since 1970); the top fifth gained 28.3\%; the Gini index increased by $19.0 \%$. Household income showed a greater inequality due to the increased percentage of families headed by a single mother, a fact not prevalent until the late 1960s or early 1970s. In fact "Household income inequality was generally stable between 1967 and 1980" (13), but then the inequality began in earnest. In a seminal paper written in 2000, the authors begin to look for economic causes: "Changes in the labor market in the 1980s included a shift from goods producing industries (that had disproportionally provided high-wage opportunities for low skilled workers) to technical service industries (that disproportionally employ college graduates) and low-wage industries, such as the retail trade. But within-industry shifts in labor demand away from the less-educated workers are, perhaps, a more important explanation of eroding wages than the shift out of manufacturing. Other factors related to the downward trend in wages of less-educated workers include intensifying global competition and immigration, the decline of the proportion of workers belonging to unions, the decline in the real value of the minimum wage, the increasing need for computer skills, and the increasing use of temporary workers" (13). This is echoed in a New York Times article by David Leonhardt (14) 
The quick response is to call for an increase in the level of education among American workers, but that would assume a more homogeneous country like Germany, as opposed to the heterogeneity of the U.S. To put it another way, there is a block of our population, who by reasons of choice or outside pressures, will have only a high school education, or less. So called free trade has left America bereft of semi-skilled jobs.

\section{COMPENSATION BY MANUFACTURING VERSUS ALL PRIVATE MANUFACTURERS}

An important fact about manufacturing is its superior wage differential as compared to non-manufacturing industries, e.g. distribution or service. Chart Three shows the premium paid by manufacturing companies compared to all private industries with the latter a proxy for non-manufacturing (15). The premium has risen from $11 \%$ in 1950 to $23 \%$ in 2010 . Of course, "manufacturing wages are high largely because production is capital-intensive and technologically sophisticated. As a result, educational requirements have risen. Now, more than half of manufacturing workers have some college education, up from just over $20 \%$ in 1969." (16). And "In the two decades prior to the recession, labor productivity in manufacturing roughly doubled, with output rising 65 percent and labor hours declining by 20 percent". (4) But unless one expects that total American output trend to be relatively flat, the above quotes explain the wage premium but not the fact that manufacturing employment has plummeted. For the most part, companies make significant productivity investments because of expected expansion of sales, not just to fire people.

Chart Three: Manufacturing Compensation Premium for Manufacturing Compensation versus All Private Industries

\begin{tabular}{cc}
\hline Year & Premium \\
\hline 2010 & $23.0 \%$ \\
2000 & $20.3 \%$ \\
1990 & $19.4 \%$ \\
1980 & $18.4 \%$ \\
1970 & $11.6 \%$ \\
1960 & $16.5 \%$ \\
1950 & $11.0 \%$ \\
\hline
\end{tabular}

Source: Bureau of Economic Analysis, U.S. Department of Commerce, courtesy of the Manufacturing Institute

\section{IS THE ANSWER AN INDUSTRIAL POLICY?}

In discussing the causes of the decline of manufacturing as a percentage of GDP, certain tax law changes, suggested by the White House, immediately raised the debate of whether the U.S. should engage in an industrial policy. One of the best economic definitions of Industrial policy states: "Governments try to influence their nation's economies in two ways: either with economy wide policies, such as tightening credit or taxing capital gains; or with sector specific policies, such as deregulating the airlines, or protecting textiles from Asian imports. The latter are industrial policies; together aimed strategically towards certain national goals, they make up Comprehensive Industrial policy (IP). Industrial policy denotes a nation's declared, official, total effort to influence sectoral development and, thus, national industrial portfolio. Industrial policies are the component parts of IP. In European practice, generally developed in American discussion, 'industrial' means the manufacturing but not the agricultural components of the goods-producing sectors." (17) The issue then is should the government take on a policy that strengthens manufacturing, in effect altering the results of over sixty years of so-called free trade?

Dealing head on with the Theory of Comparative Advantage is the noted economist (and free trade advocate) Princeton University's Paul Krugman. As early as 1986 he stated: "the idealized theoretical model on which the classical case for free trade is based will not serve us anymore. The world is more complex than that, and there is no question that complexities do open, in principle, the possibility of successful activist trade or industrial policy." (18) By 2007, he continues to see the benefits of trade between countries with similar economies, e.g. U.S. and Canada, creating a mutual benefit, presumably reflecting the principles of Comparative Advantagespecialization and expanding markets. However he goes on to say: "trade between countries at very different economic development tends to create large classes of losers as well as winners... when the effects of third world 
exports on U.S. wages first became an issue in the 1990s, a number of economists - myself included - looked at the data and concluded that any negative effects on U.S. wages were modest. The trouble now is that these effects may no longer be modest as they were, because imports of manufactured goods from the third world have grown dramatically - from just under 2.5 percent of G.D.P. in 1990 to 6 percent in 2006.” (19).

At the end of the day, we already have an industrial policy. The beneficiaries of our current trade policies are multinationals that need the expanding markets that worldwide free trade provides. But they outsource to offshore economies for two reasons: as stated above those economies lack a myriad of regulations that result in lower costs, and to be fair, those countries have markets for the products that may have been originally for the U.S. market. But more than that, thanks to lobbying for beneficial trade or tax treatment, the real winners have been "commodities, intellectual property, finance and agribusiness", not manufacturing. (5)

Free trade has always had backers on both ends of the political spectrum. Trade has benefitted the developing countries, raising standards of living across the globe. Besides the humanitarian benefit, with few exceptions, mutual economic benefits reduce the possibility of war. Nobel laureate Friedrich Hayek demonstrated that political liberties and economic freedoms are interdependent; thus the trade component of capitalism has fostered democracy. But it should be recognized that such trade policies, including international trade agreements, and the eliminations of quotas and tariffs, are part of an industrial policy.

Critics of industrial policy, especially those that favor smaller federal government, argue that the government should not be picking winners and losers. But the fact is that our existing policies favor multinationals, energy and commodity producers, and the service sectors of banking and finance. And those same critics of a federal industrial policy are state governors who, through tax abatements and monies for training, favor companies who can produce local jobs and tax revenue.

An industrial policy that lowers the cost of capital for manufacturers is the major alternative to constraining trade. Current tax proposals favoring manufacturing would go a long way for that reduction. Making permanent an R\&D tax credit would help reduce uncertainty towards capital investment. As mentioned above, "level playing field" accounting, where capital expenditures are expensed and not depreciated, would foster manufacturing through a much lower cost of capital. The Investment component of GDP would expand greatly, as would job creation. And to answer those critics that say that manufacturing is "not more important in the economy than retail or distribution or anything else" (20), one can only point out the wage levels of manufacturing and its large multiplier effect.

\section{CONCLUSION}

Manufacturing, in the U.S. is alive and well, despite its shrinking share of our economy. However, if one extrapolates America with a GDP that reflects a much larger manufacturing component, the re-creation of highpaying, middle class jobs would go a long way towards reducing that polarization of wealth and income in America.

\section{AUTHOR INFORMATION}

Mr. Dunn is currently a part time Faculty member of the Economics and Legal Studies Department of Robert Morris University. He is also President of J.H. Dunn and Company, which provides strategic and financial advisory services to middle market corporate clients. Recent assignments have included advising the shareholders on a divestiture, two corporate sales, four acquisitions, and an independent valuation of a private company. He has served on several corporate boards, including a Houston based container manufacturing company; a Pittsburgh based manufacturer of refractory products; and on the advisory board of a manufacturer of titanium products. Prior to establishing his company, Mr. Dunn was a Managing Director of PNC Capital Markets for ten years, actively involved in the Mergers \& Acquisitions for the corporate clients of PNC Financial Services Group. Prior to PNC, Mr. Dunn spent most of his career with commercial and investment banks, including Citigroup and before that, with the CIT Group. Recently he was appointed as a member of the Pittsburgh Business Advisory Council, of the Pittsburgh Branch of the Federal Reserve Bank of Cleveland. Mr. Dunn holds an AB Degree from Princeton University and an MBA from the University of South Carolina. E-mail: dunnj@rmu.edu 


\section{REFERENCES}

1. $\quad$ Andy Grove, How America Can Create Jobs, Bloomberg Business Week, July 26, 2010.

2. Louis Uchitelle, Is Manufacturing Off The Radar?, The New York Times, September 10, 2011

3. Dennis Lockhart, President of the Atlanta Federal Reserve Bank, A View of U.S. Manufacturing, Knoxville Economics Forum, April 8, 2011

4. Sandra Pianalto, President of the Cleveland Federal Reserve Bank, U.S. Manufacturing and the Economic Outlook, October 20, 2011

5. Carl Pope, America's Dirty War Against Manufacturing, Parts 1,2,3, Bloomberg Business Week, January 18-20, 2012

6. Fred Hosier, Worker fatalities: How does China compare to U.S.?, www.safetynewsalert.com , March 4, 2010

7. David Barboza, After Suicides, Scrutiny of China's Grim Factories, The New York Times, June 6, 2010

8. Dan Slater, The Debate Over Who Pays fees When Litigation Mounts Attacks, The Wall Street Journal, December 23, 2008

9. National Association of Manufacturers, Facts About Manufacturing, www.nam.org, from the U.S. Bureau of Economic Analysis, Industry Economic Accounts (2009)

10. Timothy Considine, Ph.D., Robert Watson, Ph.D., P.E., Rebecca Entler, Jeffrey Sparks, An Emerging Giant: Prospects and Economic Impacts of Developing the Marcellus Natural Gas Play, The Pennsylvania State University, August 5, 2009

11. Corrado Gini, Variability and Mutability, 1912

12. U. S. Census Bureau

13. Arthur F. Jones, Jr. and Daniel H. Weinberg, The Changing Shape of the Nation's Income Distribution, 1947-1998, U.S Census Bureau

14. David Leonhardt, Income Inequality, The New York Times, January 18, 2011.

15. Gardner Carrick, the Manufacturing Institute, and from the Bureau of Economic Analysis, Manufacturing Compensation Premium, February 7, 2012

16. Christina D. Romer, Do Manufacturers need Special Treatment?, The New York Times, February 4, 2012

17. Otis L. Graham, Jr., Losing Time: The Industrial Policy Debate, Harvard University Press, 1992

18. Paul R. Krugman, Strategic Trade Policy and the New International Economics, the Massachusetts Institute of Technology Press, 1986

19. Paul R. Krugman, Trouble With Trade, The New York Times, December 28, 2007

20. Binyamin Appelbaum, Winners and Losers From a Tax Proposal, The New York Times, February 22, 2012

21. Bureau of Industry and Security, U. S. Department of Commerce, The U.S. Textile and Apparel Industries: An Industrial Base Assessment, Report to Congress 2003 